\title{
SPRAY NOZZLE PATTERN TEST FOR THE DWPF HEME TASK QA PLAN (U)
}

by'

L. Lee

Westinghouse Savannah River Company

Savannah River Site

Aiken, South Carolina 29808

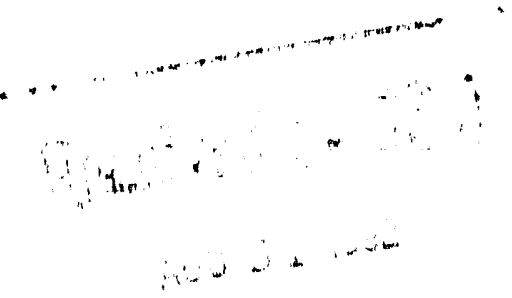

This report was prepared in connection with work done under Contract No. DE-ACO9-89SR18035 with the U.S. Department of Energy. By acceptance of this report, the publisher andior recipient acknowledges the U.S. Government's right to retain a nonexclusive, royalty-free license in and to any copyright covering this report, alon's with the right to reproduce and to authorize others to reproduce all or part of the copyrighted report. 


\section{DISCLAIMER}

This report was prepared as an account of work sponsored by an agency of the United States Government. Neither the United States Government nor any agency thereof, nor any of their employees, makes any warranty, express or implied, or assumes any legal liability or responsibility for the accuracy, completeness, or usefulness of any information, apparatus, product, or process disclosed, or represents that its use would not infringe privately owned rights. Reference herein to any specific commercial product, process, or service by trade name, trademark, manufacturer, or otherwise does not necessarily constitute or imply its endorsement, recommendation, or favoring by the United States Government or any agency thereof. The views and opinions of authors expressed herein do not necessarily state or reflect those of the United States Government or any agency thereof.

This report has been reproduced directly from the best available copy.

Available to DOE and DOE contractors from the Office of Scientific and Technical Information, P.O. Box 62, Oak Ridge, TN 37831; prices available from (615) 576-8401, FTS 626-8401.

Available to the public fron the National Technical Information Service, U.S. Department of Commerce, 5285 Port Royal Rd., Springfield, VA 22161. 
Westinghouse Savarnah River Company Savannah River Laboratory

WSRC.RP-91-1175

Keywords: HEME, HEPA, Spray Pattern, Spray Nozzle

Retention period:permanent

CC. E. W. Holizscheiter, 773-A

E. T. Booth, 704-T

T. K. Snyder, 704-T

R. E. Roaden, 704-T

J. F. Sides, 679-T

P. R. Burket, 704-27S

L. A. Patterson, 704-30S

SRL Records (2)

To: C. T. Randall, 704-T

From: L. Lee, 704-T Ree

November 25, 1991

\section{SPRAY NOZZLE PATTERN TEST FOR THE DWPF HEME TASK QA PLAN (U)}

\section{INTRODUCTION:}

The DWPF melter off-gas systems have two High Efficiency Mist Eliminators (HEME) upstream of the High-Efficiency Particulates Air filters (HEPA) to remove fine mists and particulates from the off-gas. To have an acceptable filter life and an efficient operation, an air-atomized water is spray on the HEME. The water spray keeps the HEME wet and dissolves the soluble particulates and enhances and HEME efficiency.

DWPF Technical asked SRL to determine the conditions which will give satisfactory atomization and distribution of water so that the HEME will operate efficiently. The purpose of this document is to identify QA controls to be applied in the pursuit of this task (WSRC-RP-91-1151).

Authorized Derivative Classifier

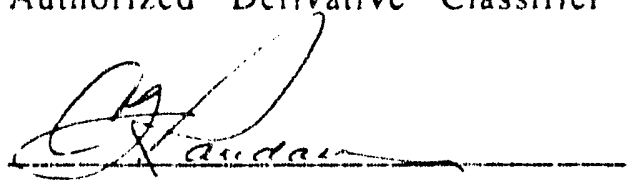

C. T. Randall 


\section{ADDITIONAL COMMENTS:}

This task will be controlled by Procedure DWP\&HT 2-3 of the SRL Defense Waste Processing and Hydrogen Technology (DWP\&HT) Quality Assurance Manual (1Q43). This procedure is an implements the Savannah River Site (SRS) 1Q Manual.

The primary service organization for this task will be TOS Works Engineering and TOS Operations Group. Work performed by TOS will be controlled by TOS QA procedures contain in 1Q27 and L8 as applicable.

The sketch describing the nozzle experiment facility is documented in Lab. Notebook \#E58091. This sketch was provided to TOS for assembly.

\section{DOCUMENTS REQUIRING CUSTOMIER REVIEW:}

(1) The Technical Task Plan (WSRC-RP-91-1151)

(2) The Task QA Plan (WSRC-RP-91-1175)

(3) The final summary report

\section{RECORDS:}

The following documentation, generated during the course of this task, shall become Quality Assurance Records:

(1) The Task Technical Plan (WSRC-RP-91-11511.

(2) The Task QA Plan (WSRC-RP-91-1175).

(3) Preliminary Test Results (SRL-PMC-0088).

(4) Controlled Laboratory Note Book (\$58091)

(5) Job Plans as needed to provide supporting documentation.

(6) Final report of this task.

All QA records generated in the performance of this iask shall be deemed lifetime records.

\section{ATTACHMENT:}

Attachment 1 - Task QA Plan Checklist. 
Review and Approvals:

Reviewed By:

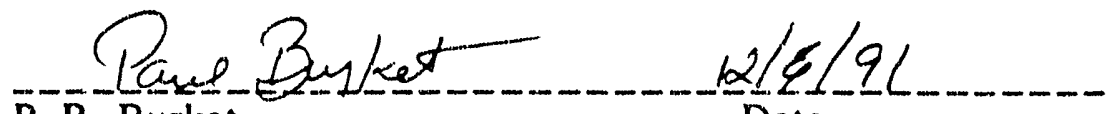
P. R. Burket Date

DWPF Technical

Approved By:
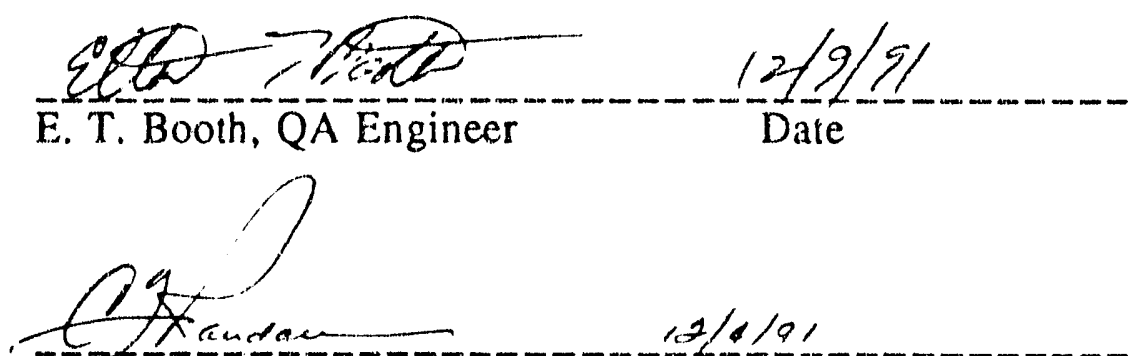

C. T. Randall, Manager Date

Process Modeling \& Control Group

Service Organization Concurrence:

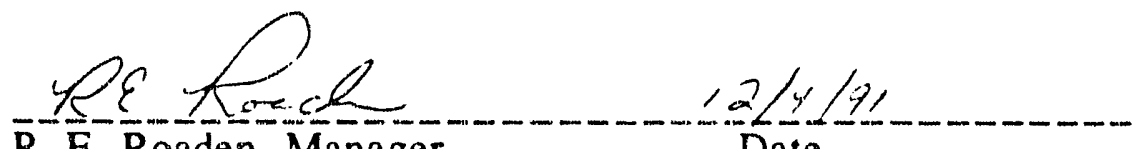

R. E. Roaden, Manager

Date

TOS Works Engineering

J.F. Sides

J.F. Sides, Manager

TOS Operations Group 


$$
\text { A: }: a:-\infty \operatorname{sen} \mid
$$

TaSkTILle SPRAV VOZZ:E PATTEWW

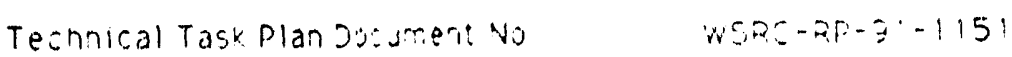

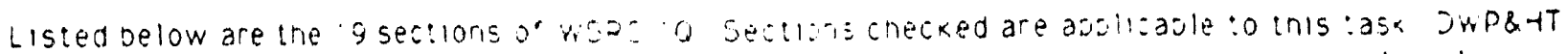

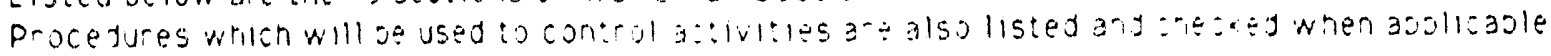

\begin{tabular}{|c|c|c|c|}
\hline WSRC IO SECTION & $\begin{array}{l}\text { Appllas } \\
\text { to Task }\end{array}$ & JWf:-4T QA Procedures & 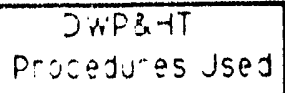 \\
\hline organization & $x$ & $\begin{array}{l}\text { JWP\&HT } 1 \text { : Organization } \\
\text { jWP\&.nT } 1 \text {-2 Stop work }\end{array}$ & $\begin{array}{l}x \\
x\end{array}$ \\
\hline QA Program & $x$ & 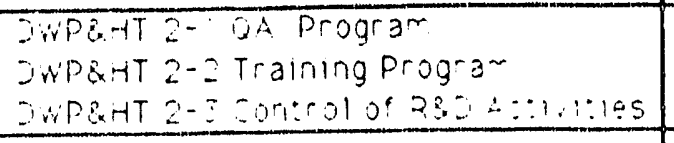 & $\begin{array}{l}x \\
x \\
x\end{array}$ \\
\hline Jesign Control & NA & NA & \\
\hline $\begin{array}{l}\text { Frocurement Documer: } \\
\text { control }\end{array}$ & NA & JWPEHT 4- Frocuremen: & $\overline{V A}$ \\
\hline $\begin{array}{l}\text { nstructions procedjes } \\
\text { and Drawings }\end{array}$ & $x$ & JW'P\&HT 5- Procedures/ins:- J::10ns & $x$ \\
\hline $\begin{array}{l}\text { Control of Purchasej } \\
\text { tems \& Services }\end{array}$ & NA & JWPBHT 4-" Procuremen: & VA. \\
\hline $\begin{array}{l}\text { dentification and } \\
\text { control of items }\end{array}$ & $x$ & 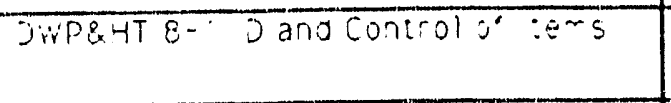 & $x$ \\
\hline Jocument control & $\bar{x}$ & 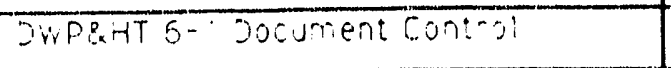 & $\bar{x}$ \\
\hline Control of Processes & $\overline{N A}$ & NA & \\
\hline ispection & $x$ & $3 W P B_{4} 1: \cdots$ nspection & $x$ \\
\hline Test Control & NA & JWPEHT - Test Conirol & $\sqrt{A}$ \\
\hline $\begin{array}{l}\text { Eontrol of Measuring } 3 \\
\text { Tesi Equipment }\end{array}$ & $\bar{x}$ & SWPZHT IE- Control OfMETE & $\bar{x}$ \\
\hline $\begin{array}{l}\text { Fackajing, Handling. } \\
\text { Snipoing \& Storage }\end{array}$ & NA & 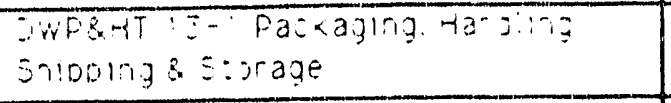 & VA \\
\hline $\begin{array}{l}\text { Tspec: } 10 n, \text { Test and } \\
\text { Goerating Status }\end{array}$ & $x$ & 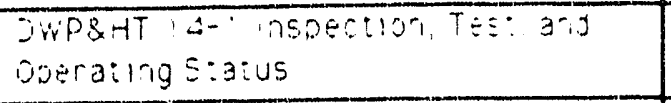 & $x$ \\
\hline $\begin{array}{l}\text { Eontrol of Noncorifo-ming } \\
\text { :tems and Actions }\end{array}$ & $x$ & 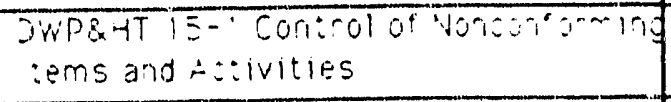 & $x$ \\
\hline $\begin{array}{l}\text { Sorrective Actions } \\
\text { System }\end{array}$ & $x$ & JWPEHT IE-' Coriective AC:IiT & $x$ \\
\hline $\begin{array}{l}\text { S. Jal!: Assurance } \\
=60 \text { ordy }\end{array}$ & A & 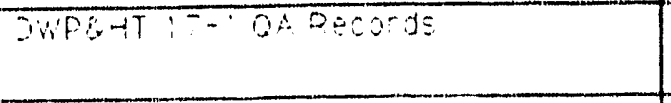 & $x$ \\
\hline Audits & $x$ & 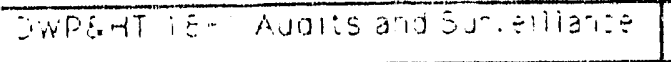 & $\lambda$ \\
\hline $\begin{array}{l}\text { Eoftware oualliy } \\
\text { Assurarce }\end{array}$ & $\sqrt{\hat{\prime}}$ & $\sqrt{A}$ & \\
\hline
\end{tabular}



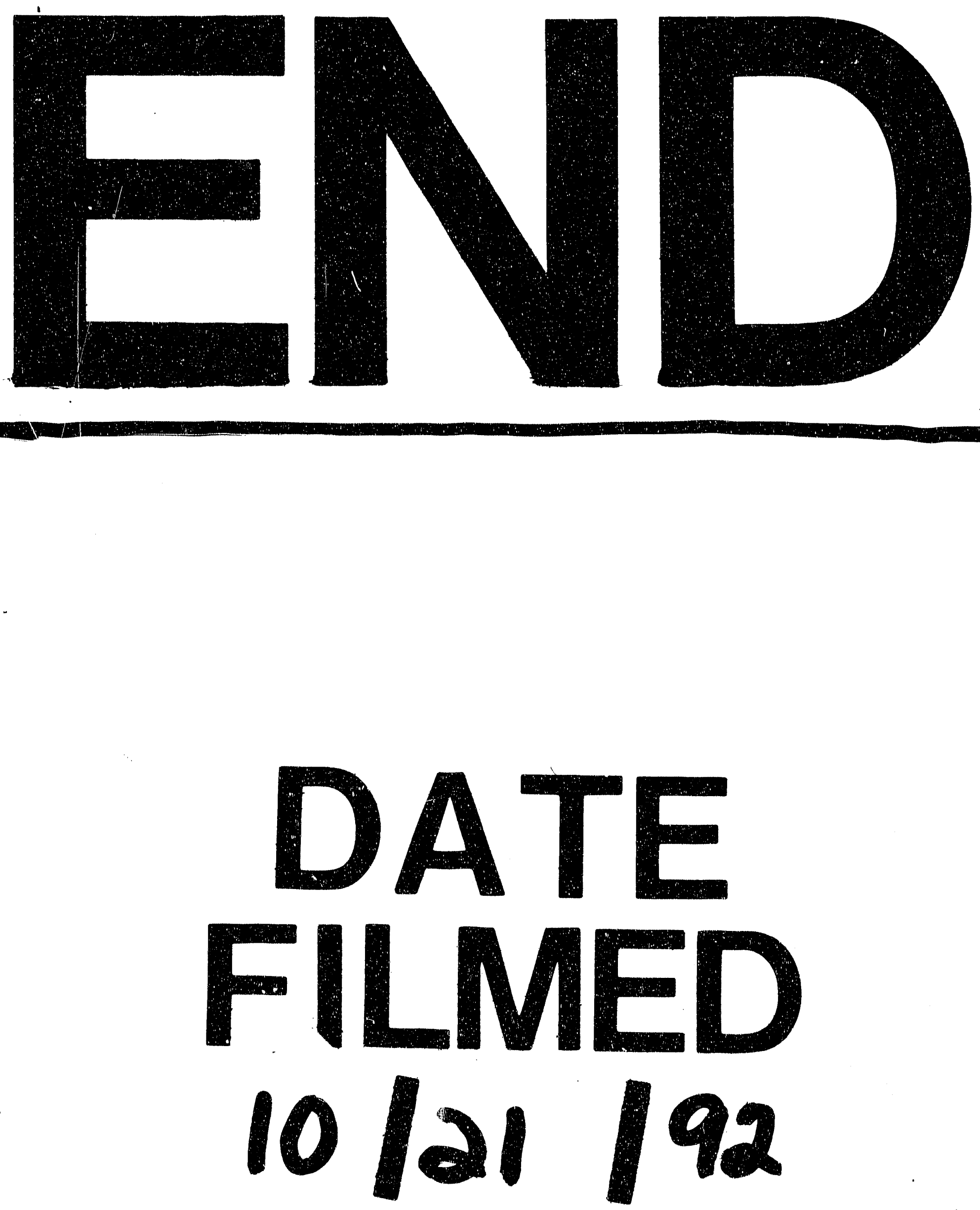

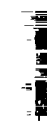


$\frac{\underline{\underline{\underline{\underline{\underline{\underline{E}}}}}}}{\underline{\underline{\underline{\underline{\underline{E}}}}}}$ 